\title{
IMPLEMENTASI UJI KOMPETENSI DAN PENGARUHNYA TERHADAP KUALITAS LULUSAN SMK NEGERI BIDANG TEKNOLOGI DI PROVINSI BALI
}

\author{
Oleh \\ Nyoman Santiyadnya \\ Jurusan Teknik Elektronika, FTK, UNDIKSHA
}

\begin{abstract}
ABSTRAK
Sekolah Menengah Kejuruan (SMK) merupakan sekolah menengah yang bertujuan mencetak lulusannya menjadi tenaga-tenaga terampil dan profesional dibidangnya sesuai dengan program studi keahliannya yang selalu berwawasan pada masa depan dan sesuai dengan kebutuhan pasar. Tujuan penelitian ini adalah untuk mengetahui kualitas pelaksanaan uji kompetensi di SMK teknologi dan pengaruhnya terhadap profesionalisme lulusannya. Untuk mendapatkan data terkait kualitas pelaksanaan uji kompetensi dilakukan dengan cara observasi langsung ke SMK, sedangkan data profesionalisme lululusan dilakukan penelusuran alumni. Data yang diperoleh kemudian di deskripsikan guna memperoleh gambaran tentang kualitas uji kompetensi dan pengaruhnya terhadap lulusan SMK. Dari hasil analisis diketahui bahwa untuk mencapai kompetensi keahlian tersebut ada babarapa hal yang menjadi bahan pertimbangan, yaitu: perkembangan teknologi, pasar kerja, pertambahan penduduk, perubahan pola kerja, konsep keunggulan lokal, sarana prasarana, jumlah dan mutu guru. Untuk mencetak lulusan SMK yang mampu mandiri dan profesional sangat diperlukan jumlah dan mutu guru serta sarana prasarana yang memadai dengan memperhatikan keunggulan lokal di mana SMK tersebut berada. Dengan demikian lulusan SMK dapat memenuhi pasar kerja.
\end{abstract}

Kata kunci: SMK teknologi, uji kompetensi, profesionalisme lulusan.

\begin{abstract}
Special skill middle school (SMK) to shape the middle school which having a goal produce a graduate to become skillful and professional worker in according with special skill which always to think of future time and according with needs market. The destination this research is find out quality of competency test in SMK technology and that effect regarding for professionalism a grduate. To find data caught the quality of implementation for competency test done with direct observation to SMK wich data for professionalisme a graduate done with tracer study. Data wich obtained then given a discription a use to obtain an image about quality competency test and an effect a graduate for SMK. For output analysis known that to achieve that ability competency there is some matter which happen element judgment, that is development technology, a work market, increase
\end{abstract}


population, transition work model, excellence local concep, facility and infrastructure, quantity and quality teacher. To produce a graduate SMK which independently and professional very needed quantity and quality teacher including which satisfy facility and infrastructure with local excellence where the SMK mentioned to exist. With such a graduate for SMK can conform to market worker.

Keywords: SMK technology, competency test, professionalism a graduate

\section{PENDAHULUAN}

Berdasarkan Undang-undang Republik Indonesia No. 20 Tahun 2003 tentang Sistem Pendidikan Nasional definisi Sekolah Menengah Kejuruan (SMK) adalah:

"Pendidikan kejuruan merupakan pendidikan yang mempersiapkan peserta didik untuk dapat bekerja dalam bidang tertentu."

Peraturan Pemerintah No.19 Tahun 2005 Tentang Standar Pendidikan Nasional, menjelaskan Sekolah Menengah Kejuruan secara lebih spesifik, bahwa:

"Pendidikan menengah kejuruan adalah pendidikan pada jenjang pendidikan menengah yang mengutamakan pengembangan kemampuan siswa untuk jenis pekerjaan tertentu. "

Dahulu, citra SMK sebagai sekolah kelas dua setelah SMA (Sekolah Menengah Atas, atau yang dikenal juga dengan sebutan SMU atau Sekolah Menengah Umum) sangat melekat di benak masyarakat. Banyak orang tua beranggapan bahwa, jalan sukses bagi anak-anak adalah dengan menyekolahkannya ke SMA, dengan harapan setelah lulus dapat melanjutkan ke perguruan tinggi. Menyandang predikat sarjana dianggap merupakan suatu jaminan mendapatkan pekerjaan yang lebih baik.

Akan tetapi fakta menunjukkan lain. Sejak krisis ekonomi yang dihadapi Indonesia pada tahun 1997, angka pengangguran tidak berkurang, namun justru setiap tahun makin bertambah. Struktur tenaga kerja di Indonesia menggambarkan dari 76 juta tenaga kerja ternyata didominasi oleh tenaga kerja yang tidak memiliki keterampilan (unskilled labor) dan hanya 19 juta tenaga kerja diantaranya yang 
memiliki keterampilan. Sementara itu, tenaga kerja yang memiliki keahlian (atau dengan kualifikasi ahli/expert) hanya sejumlah 4,5 juta pekerja. Melihat kondisi seperti ini, Indonesia akan sulit bersaing dengan negara lain dalam menghadapi era globalisasi seperti sekarang. Belajar dari hal tersebut, Indonesia harus mengembangkan sistem pendidikannya untuk dapat mencetak dan meningkatkan tenaga siap kerja, yang sekaligus juga dapat mencegah bertambahnya pengangguran. Sekolah kejuruan (SMK) menjadi salah satu komponen yang patut dikembangkan untuk menyiapkan sumber daya manusia yang cukup potensial tersebut.

Sekolah Menengah Kejuruan (SMK) merupakan sekolah menengah yang bertujuan mencetak lulusannya menjadi tenaga-tenaga terampil dan profesional dibidangnya sesuai dengan program studi keahliannya yang selalu berwawasan pada masa depan dan sesuai dengan kebutuhan pasar. Dantes (2007) dalam makalahnya yang berjudul "Perspektif dan Kebijakan Pendidikan Menghadapi Tantangan Global" menyatakan Pendidikan berwawasan masa depan diartikan sebagai pendidikan yang dapat menjawab tantangan masa depan, yaitu suatu proses yang dapat melahirkan individu-individu yang berbekal pengetahuan, keterampilan, dan nilai-nilai yang diperlukan untuk hidup dan berkiprah dalam era globalisasi. Pendidikan di era global ini dilaksanakan dengan bersandar pada empat pilar pendidikan, yaitu learning to know, learning to do, learning to be, dan learning to live together. Dalam learning to know peserta didik belajar pengetahuan yang penting sesuai dengan jenjang pendidikan yang diikuti. Dalam learning to do peserta didik mengembangkan keterampilan dengan memadukan pengetahuan yang dikuasai dengan latihan (law of practice), sehingga terbentuk suatu keterampilan yang memungkinkan peserta didik memecahkan masalah dan tantangan kehidupan. Dalam learning to be, peserta didik belajar menjadi individu yang utuh, memahami arti hidup dan tahu apa yang terbaik dan sebaiknya dilakukan, agar dapat hidup dengan baik. Dalam learning to live together, peserta didik dapat memahami arti hidup dengan orang lain, dengan jalan saling menghormati, saling menghargai, serta memahami tentang adanya saling ketergantungan (interdependency). Dengan keempat pilar tersebut diharapkan lulusan SMK dapat menjadi individu yang 
mandiri dan menguasai teknologi sesuai dengan bidang keahliannya serta dapat mengaplikasikan ilmu dan teknologi yang dikuasainya dalam kehidupan bermasyarakat.

Dalam spektrum keahlian pendidikan menengah kejuruan yang dicanangkan oleh Direktorat Jenderal Mendikdasmen terdapat 6 bidang studi, 40 program keahlian, 121 kompetensi keahlian SMK. Salah satunya adalah program keahlian Teknik Elektronika. Dalam program keahlian Teknik Elektronika, kompetensi keahlian yang harus dimiliki adalah Teknik audio-video, Teknik Elektronika Industri, dan Teknik Mekatronika. Namun di sisi lain untuk mencapai kompetensi keahlian tersebut ada babarapa hal yang menjadi bahan pertimbangan, yaitu: perkembangan teknologi, pasar kerja, pertambahan penduduk, perubahan pola kerja, konsep keunggulan lokal, sarana prasarana, jumlah dan mutu guru. Untuk mencetak lulusan SMK yang mampu mandiri dan profesional sangat diperlukan jumlah dan mutu guru serta sarana prasarana yang memadai dengan memperhatikan keunggulan lokal di mana SMK tersebut berada. Dengan demikian lulusan SMK dapat memenuhi pasar kerja yang ada. Kementrian Pendidikan Nasional dengan Peraturan Menteri no. 40 tahun 2008 telah mengatur standar sarana dan prasarana yang harus dimiliki oleh suatu SMK. Untuk dapat memenuhi standar tersebut pihak Kementrian Pendidikan Nasional juga telah melimpahkan beberapa kali proyek pengadaan sarana dan prasarana bagi SMK, termasuk proyek pengadaan laptop dan LCD bagi seluruh SMK. Hal ini dilakukan dalam rangka menghadapi tantangan global, lulusan SMK harus memiliki daya adaptasi yang kuat, mampu berbahasa inggris, serta menguasai ICT. Dengan menguasai ICT diharapkan lulusan SMK dapat memiliki daya saing yang tinggi dalam mencari atau menciptakan lapangan kerja. Namun kenyataan di lapangan ternyata tidak semua lulusan SMK dapat diterima di dunia kerja. Padahal pemerintah telah menetapkan standar kelulusan SMK melalui Peraturan Menteri (Permen) no. 45 tahun 2010 tentang kriteria kelulusan peserta didik SMK. Namun dalam Permen tersebut ditetapkan bahwa siswa SMK dapat dinyatakan lulus UN apabila nilai rata-rata NA minimal 5,5 sedangkan nilai setiap mata pelajaran minimal 4,0 dengan proporsi nilai $40 \%$ dari UN dan $60 \%$ dari nilai 
ujian sekolah (US). Merujuk dari standar minimal nilai tersebut tentunya tidaklah terlalu sulit bagi seorang siswa SMK untuk memperoleh nilai tersebut. Sementara Uji kompetensi yang merupakan uji keterampilan yang wajib diikuti oleh seorang siswa SMK dan dilakukan oleh pihak eksternal sebenarnya di beberapa SMK sudah dilaksanakan dengan baik, namun kriteria penilaian yang digunakan masih berbedabeda. Dengan kondisi seperti ini akan sangat sulit mengukur tingkat kompetensi lulusan SMK. Hal ini terlihat dari daya serap lulusan SMK, misalnya lulusan SMK Teknik Elektronika pada tahun 2000 daya serap lulusannya mencapai 87\% namun pada tahun 2006 daya serap lulusannya melorot tajam sampai 50,5\%. Hal ini terjadi karena kompetensi yang dibutuhkan oleh lapangan kerja meningkat secara pesat, namun kompetensi lulusan SMK tidak mengalami peningkatan yang signifikan. Sehingga untuk mendapatkan lulusan SMK yang memenuhi kompetensi yang dibutuhkan di dunia kerja perlu dilakukan upaya atau kiat-kiat untuk membenahi pelaksanaan uji kompetensi (ujian praktik) bagi seluruh SMK. Namun upaya pembenahan tersebut bukanlah hal yang mudah karena setiap SMK memiliki karakter yang berbeda-beda.

Dari paparan di atas dapat dirumuskan permasalahan yang harus mendapatkan pemecahan, yaitu: 1) Bagaimana pelaksanaan uji kompetensi bagi siswa SMK yang telah berlangsung selama ini? 2) Apa saja yang menjadi kendala dalam pelaksanaan uji kompetensi siswa SMK? 3) Bagaimana kiat-kiat yang harus dilakukan dalam menyelesaikan kendala pelaksanaan uji kompetensi siswa SMK tersebut? 4) Bagaimana pengaruh uji kompetensi terhadap profesionalisme lulusan SMK?

Untuk mendapatkan data terkait pelaksanaan uji kompetensi, peneliti harus melakukan observasi ke SMK-SMK bidang teknologi yang ada di Bali pada saat SMK tersebut melaksanakan uji kompetensi. Kesiapan sekolah dan dukungan sarana prasarana akan sangat mempengaruhi kualitas pelaksanaan uji kompetensi di SMK tersebut. Sementara itu, untuk mengetahui pengaruh pelaksanaan uji kompetensi terhadap profesionalisme lulusan perlu dilakukan penelusuran alumni guna mendapatkan data otentik terkait profesionalisme lulusan tersebut. Dari data-data 
tersebut dapat dijadikan acuan melakukan evaluasi terkait pelaksanaan uji kompetensi di SMK bidang teknologi.

Dengan demikian nantinya akan dapat dilakukan standarisasi pelaksanaan uji kompetensi di SMK bidang teknologi sesuai dengan kurikulum yang berlaku, sehingga daya serap lulusan SMK di dunia usaha/industri dapat meningkat sampai $100 \%$ sesuai dengan tujuan pendidikan Nasional.

\section{PEMBAHASAN}

Melihat peluang besar dan peran penting sekolah kejuruan dalam upaya penyiapan tenaga kerja siap pakai untuk menekan tingkat pengangguran dan meningkatkan pertumbuhan ekonomi Indonesia, perubahan paradigma penyelengaraan pendidikan kejuruan mulai dilakukan. Perubahan paradigma tersebut terjadi pada orientasi pendidikan dan pelatihan kejuruan yang dikembangkan dari yang bersifat supply driven menjadi demand driven. Sistem pengelolaan yang mulanya bersifat sentralistik, berubah menjadi desentralistik. Pendekatan pembelajarannya pun bergeser, dari pendekatan mata pelajaran menjadi pembelajaran berbasis kompetensi. Pola penyelenggaraan pendidikan dan pelatihan pun berkembang dari yang semula sangat terstruktur menjadi lebih fleksibel/luwes dan permeable/terbuka.

SMK sebagai bentuk satuan penyelenggara dari pendidikan menengah kejuruan yang berada di bawah Direktorat Pembinaan Sekolah Kejuruan, merupakan lembaga pendidikan yang berorientasi pada pembentukan kecakapan hidup, yaitu melatih peserta didik untuk menguasai keterampilan yang dibutuhkan oleh dunia kerja (termasuk dunia bisnis dan industri), memberikan pendidikan tentang kewirausahaan, serta membentuk kecakapan hidup (life skill). Pembelajaran di SMK lebih ditekankan untuk melakukan praktik, sehingga mereka berpengalaman dan mantap untuk langsung memasuki dunia kerja, tetapi ini tidak menutup kemungkinan para lulusan SMK untuk dapat melanjutkan ke jenjang pendidikan yang lebih tinggi. Sehingga Kurikulum di SMK harus mampu mengakomodasi kebutuhan peserta didik yang berbeda secara individual, baik ditinjau dari segi 
waktu maupun kemampuan belajar (Balitbang, 1999(b)). Oleh karena itu, merumuskan suatu kurikulum sudah barang tentu bukan hal yang mudah. Banyak faktor yang menentukan dalam proses lahirnya sebuah kurikulum.

Sekolah kejuruan sebagai salah satu lembaga pendidikan formal yang ada di Indonesia, dituntut juga untuk terus mengikuti dan menerapkan berbagai perubahan kurikulum dalam periode tertentu sesuai dengan kebijakan pemerintah dalam sistem pendidikan nasionalnya. Sekolah kejuruan berbeda dengan sekolah umum, terutama kompetensi lulusannya serta keterkaitannya secara langsung dengan dunia kerja, menyebabkan kurikulum untuk sekolah kejuruan tidak pernah bisa dilepaskan dari kondisi dan situasi dunia kerja yang sedang berkembang. Penyesuaian kurikulum dengan dunia kerja serta tetap dilandasi oleh minat dan kebutuhan siswa, menjadikan kurikulum sekolah kejuruan memiliki kerumitan tertentu, baik dalam proses penyusunan maupun implementasinya (Balitbang, 1999(a))

Kompetensi dapat diartikan sebagai kemampuan seseorang dalam menghadapi situasi dan keadaan di dalam pekerjaannya. Kompetensi seseorang dapat dilihat dari tingkat kreativitas yang dimilikinya serta inovasi-inovasi yang diciptakan dan kemampuannya dalam menyelesaikan suatu masalah. Menurut E. Mulyasa (2005), kompetensi merupakan perpaduan dari pengetahuan, keterampilan, nilai dan sikap yang direfleksikan dalam kebiasaan berpikir dan bertindak.

Dalam menentukan kelulusan siswa, SMK menggunakan nilai hasil ujian nasional dan nilai uj kompetensi. Sampai saat ini nilai ujian nasional yang dipersyaratkan oleh pemerintah agar seorang siswa SMK dapat dinyatakan lulus adala 5,5 (reratanya) dan nilai setiap mata pelajaran minimal 4,0. Nilai ini sangat mudah dicapai oleh seorang siswa SMK, sehingga untuk mengukur kompetensi seorang siswa SMK perlu lebih ditekankan pada nilai hasil uji kompetensi. Selama ini pelaksanaan uji kompetensi dilakukan di masing-masing sekolah dengan melibatkan pihak eksternal. Dalam pelaksanaan uji kompetensi ini guru bersamasama pihak eksternal melakukan penilaian terhadap hasil ujian praktik yang digunakan sebagai nilai uji kompetensi. Uji kompetensi ini dilakukan dengan cara ujian praktik untuk menguji kemampuan/penguasaan siswa terhadap kompetensi dasar yang dipersyaratkan oleh satu mata diklat, tidak dilakukan terhadap setiap 
indikator. Sehingga gambaran kompetensi siwa yang diperoleh dari uji kompetensi in hanya berupa gambaran kemampuan secara global, sementara itu kompetensi per indikatornya belum dapat diamati, dan seringkali diabaikan.

Kita ambil satu contoh pelaksanaan uji kompetensi di SMK jurusan Teknik Audio Video, misalnya untuk kompetensi dasar membuat rangkaian elektronika, uji kompetensi (ujian praktik) yang dilaksanakan langsung terhadap kemampuan siswa membuat satu rangkaian elektronika. Padahal kalau dicermati lebih jauh, dalam memenuhi kompetensi dasar ada indikator indikator yang harus dipenuhi/dikuasai terlebih dahulu. Untuk mengukur kemampuan siswa dalam membuat rangkaian elektronika yang baik, ada beberapa indikator yang harus diukur terlebih dahulu, seperti bagaimana cara menyolder yang baik, menggambar layout, memilih komponen, dan lain-lain. Namun dalam uji kompetensi yang dilaksanakan di SMK, indikator-indikator tersebut tidak diujikan. Dengan model pelaksanaan uji kompetensi seperti ini akan sangat sulit mendapatkan data tentang kompetensi siswa secara akurat, karena kita tidak mendapatkan data hasil pengukuran terkait kemampuan siswa terhadap penguasaan indikator-indikatornya.

Sementara itu pihak luar yang dilibatkan dalam uji kompetensi seringkali tidak memperhatikan kompetensinya, karena belum memiliki sertifikat sebagai asesor namun hanya memiliki kemampuan di bidangnya yang dianggap sudah cukup ahli. Karena kalau menggunakan pihak yang sudah memiliki sertifikat sebagai asesor biayanya akan mahal sekali, sementara itu pihak sekolah tidak memiliki anggaran yang cukup untuk mendatangkan seorang asesor. Untuk menanggulangi hal tersebut sebenarnya pihak sekolah dapat mengirimkan guru yang memiliki kompetensi di bidangnya untuk mengikuti pelatihan sebagai asesor, namun pihak sekolah masih belum mampu menyediakan anggaran walaupun biayanya jauh lebih murah. Pelibatan pihak luar yang belum memiliki sertifikat sebagai asesor cenderung kurang objektif karena tidak memiliki standar penilaian yang pasti. Lain halnya kalau melibatkan asesor, mereka telah memiliki standar penilaian yang pasti dan cenderung objektif.

Kurangnya kompetensi lulusan SMK seringkali disebabkan oleh kurangnya sarana dan prasarana yang dimiliki oleh SMK tersebut, hanya SMK yang berada di 
pusat kota dan sudah lama berdiri yang memiliki sarana dan prasarana yang memadai dengan kualitas dan standar yang sesuai dengan yang dipersyaratkan. Seringkali sarana dan prasarana tersebut jarang ditera sehingga kurang baik digunakan untuk membentuk kompetensi siswa. Lain halnya dengan SMK yang ada dipinggiran, sarana dan prasarana yang dimiliki cenderung kurang baik dari segi kuantitas maupun kualitasnya. Hal ini menjadi salah satu faktor sulitnya meningkatkan kompetensi siswa SMK.

Selain sarana dan prasarana, kendala lain yang sering terjadi adalah masih adanya guru SMK kurang peka terhadap perkembangan teknologi. Hal ini akibat kurangnya keinginan guru untuk meg-update diri melalui kegiatan worskhop atau pelatihan, dan seringkali guru merasa dirinya sudah hebat dan puas dengan apa yang pernah dipelajari sewaktu kuliah di S1.

Hunt (dalam Rosyada, 2004: 113) menyatakan bahwa guru yang yang baik harus memenuhi tujuh kriteria, yaitu: 1) memiliki sifat-sifat antusias, stimulatif, mendorong siswa untuk maju, hangat, berorientasi pada tugas dan bekerja keras, toleran, sopan, bijaksana, bisa dipercaya, fleksibel, demokratis, penuh harapan bagi siswa, 2) memiliki pengetahuan yang memadai terhadap mata pelajaran yang diampunya, dan terus mengikuti kemajuan dalam bidang ilmunya, 3) mampu memberikan jaminan bahwa materi yang disampaikannya mencakup semua materi bahasan yang diharapkan siswa secara maksimal, 4) mampu menjelaskan berbagai informasi secara jelas, dan terang, memberikan layanan yang variatif, menciptakan dan memelihara momentum, menggunakan kelompok kecil secara efektif, mendorong siswa untuk berpartisipasi, memonitor dan sering mendatangi siswa, 5) mampu memberikan harapan pada siswa, mampu membuat siswa akuntabel, dan mendorong partisipasi orang tua dalam memajukan kemampuan akademik siswa, 6) mampu menerima berbagai masukan, risiko dan tantangan, selalu memberikan dukungan pada siswanya, konsisten dalam kesepakatan dengan siswa, bijaksana terhadap kritik siswa, dan 7) mampu menunjukkan keahlian dalam perencanaan, organisasi kelas sejak pertama bertugas, cepat memulai kelas, melewati masa transisi dengan baik. 
Pertimbangan yang perlu diperhatikan dalam standarisasi kompetensi guru adalah: 1) standar kompetensi dikembangkan melalui seperangkat kemampuan yang dipersyaratkan dalam tugas-tugas mengajar yang harus dikuasai oleh setiap guru pada setiap jenis dan jenjang pendidikan. Perangkat kemampuan dimaksud terdiri atas kemampuan aktualisasi, penguasaan dan kemampuan akses, sedangkan peningkatan kompetensi dititikberatkan pada peningkatan kinerja guru pada ketiga aspek tersebut sesuai dengan tuntutan kurikulum, kebutuhan peningkatan mutu pendidikan, dan struktur ilmu pengetahuan yang berkembang, 2) pengembangan standar kompetensi guru didasarkan pada asumsi-asumsi yang diangkat dari fakta empirik, pertimbangan para ahli dan pilihan nilai masyarakat yang pola pikir dan pola kehidupannya makin maju searah dengan kemajuan zaman, 3) pengembangan standar kompetensi guru dilakukan secara sistematis, yakni mulai dari kondisi individu dan masyarakat masa depan yang diharapkan, yang dirumuskan dalam bentuk pilihan nilai maupun kondisi manusia yang tidak pernah berhenti bertanya untuk memahami diri, lingkungan, dunia dan penciptanya, 4) Subtansi yang dikembangkan lebih diarahkan pada terbentuknya suatu koridor atau acuan kemampuan yang bersifat nasional dengan memberikan kesempatan seluas-luasnya kepada guru secara kreatif sesuai dengan bidang kemampuannya masing-masing, 5) standar kompetensi guru dalam peningkatan mutu pendidikan di sekolah yang sejalan dengan gerakan peningkatan mutu guru pada khususnya dan peningkatan mutu pendidikan pada umumnya.

Tingkat standarisasi kompetensi terdiri atas: standar kompetensi minimal (micro competencies), standar kompetensi menengah (mezzo competencies), standar kompetensi pendalaman (macro competencies), dan standar kompetensi spesialis (specialist competencies). Adapun kebutuhan perangkat kompetensi meliputi kemampuan yang berkenaan dengan: (a) kebijaksanaan penyelenggaraan pendidikan, (b) kepribadian dan keterampilan sosial, (c) pemahaman terhadap wawasan pendidikan, (d) manajemen pembelajaran, (e) manajemen bingbingan dan konseling, (f) manajemen administrasi sekolah, (g) pengembangan diri, (h) manajemem kegiatan ekstra kurikuler, (i) hakikat struktur keilmuan mata pelajaran yang diajarkan, (j) penguasaan materi keilmuan mata pelajaran yang diajarkan, (k) 
pemahaman karakter atau gaya belajar siswa dan prinsip-prinsip pembelajarannya, (l) keterampilan dalam mengevaluasi dan menganalisis hasilnya serta menyusun laporannya, dan (m) Mengembangkan sumber belajar.

Guru adalah semua orang yang berwenang dan bertanggungjawab terhadap pendidikan murid-murid, baik secara individual ataupun klasikal, baik di sekolah maupun di luar sekolah, ini berarti seorang guru harus memiliki ciri khas dari kompetensi sebagai wewenang dan kemampuan dalam menjalankan tugas. Ciri-ciri kompetensi tersebut adalah memiliki kemampuan pedagogik, memiliki kepribadian, menguasai bahan pelajaran, dan menguasai cara-cara mengajar yang baik. Bila guru tidak memiliki kemampuan pedagogik, tidak memiliki kepribadian, tidak menguasai bahan pelajaran, dan tidak menguasai cara-cara mengajar yang baik, maka guru gagal melaksanakan tugasnya, sebelum berbuat lebih banyak dalam pendidikan dan pengajaran. Oleh karena itu, kompetensi mutlak dimiliki guru sebagai kemampuan, kecakapan atau keterampilan dalam mengelola kegiatan pendidikan. Dengan demikian, kompetensi guru berarti pemilikan pengetahuan keguruan, pemilikan keterampilan, dan kemampuan sebagai guru dalam melaksanakan tugasnya.

Disamping penilaian terhadap kualitas guru, perlu dilakukan penilaian konteks untuk mengetahui kualitas pelaksanaan uji kompetensi. Tayibnapis (2003:14) menyatakan bahwa evaluasi konteks membantu merencanakan keputusan, menentukan keputusan yang akan dicapai oleh program, dan merumuskan tujuan program. Penilaian konteks terutama ditujukan untuk menyajikan alasan-alasan sebagai dasar dalam menentukan tujuan program agar lebih mungkin dapat dikerjakan (fleksibel) dengan kondisi dan situasi di mana program itu akan dilaksanakan. Penilaian konteks sebagai latar yang mendukung kualitas pelaksanaan uji kompetensi di SMK, meliputi: (1) visi, dan misi SMK, (2) tujuan SMK, (3) kurikulum, (4) letak geografis SMK.

Menurut R. Ibrahim (dalam Tim Pengembang MKDP, 2011: 5), kurikulum dikelompokkan menjadi 3 dimensi, yaitu: kurikulum sebagai substansi, kurikulum sebagai sistem, dan kurikulum sebagai bidang studi. Sebagai substansi, kurikulum dipandang sebagai rencana kegiatan belajar siswa di sekolah. Sementara itu 
kurikulum sebagai sistem memandang kurikulum sebadai bagian dari sistem persekolahan, sistem pendidikan, dan bahkan sistem masyarakat. Sedangkan kurikulum sebagai bidang studi, yaitu bidang studi kurikulum.

Menurut Nana Syaodih Sukmadinata (dalam Tim Pengembang MKDP, 2011:6), kurikulum dapat ditinjau dari tiga dimensi, yaitu sebagi ilmu, sebagai sistem, dan sebagai rencana. Kurikulum sebagai ilmu dikaji konsep, asumsi, teoriteori, dan prinsip-prinsip dasar tentang kurikulum. Kurikulum sebagai sistem dijelaskan kedudukan kurikulum dalam hubungannya dengan sistem-sistem lain, komponen-komponen kurikulum, kurikulum dalam berbagai jalur, jenjang, jenis pendidikan, manajemen kurikulum, dan sebagainya. Kurikulum sebagai rencana diungkapkan berbagai rencana dan rancangan atau desain kurikulum.

Menurut Said Hamid Hasan, kurikulum memiliki empat dimensi pengertian, yaitu: kurikulum sebagai ide/gagasan, kurikulum sebagai rencana tertulis yang sebenarnya merupakan perwujudan dari kurikulum sebagai ide, kurikulum sebagai suatu realita atau implementasi kurikulum yang merupakan pelaksanaan dari kurikulum sebagai rencana, kurikulum sebagai suatu hasil yang merupakan konsekuensi dari kurikulum sebagai suatu kegiatan.

Kurikulum merupakan alat untuk mencapai tujuan-tujuan pendidikan, oleh karenanya kurikulum seyogyanya selalu dievaluasi dan dikembangkan. Evaluasi merupakan bagian penting dalam proses pengembangan kurikulum. Evaluasi untuk program pelaksanaan pengembangan kurikulum di tingkat sekolah memerlukan indikator keberhasilan sebagai tolok ukur pencapaian pelaksanaan kurikulum. Indikator keberhasilan kurikulum mencakup: indikator keberhasilan sosialisasi kurikulum, indikator keberhasilan penyusunan silabus, indikator keberhasilan penyusunan program tahunan dan semester, indikator keberhasilan penyusunan rencana pembelajaran, indikator keberhasilan penyusunan bahan ajar, dan indikator keberhasilan pelaksanaan kegiatan belajar-mengajar. Evaluasi pelaksanaan kurikulum tidak hanya mengevaluasi hasil belajar peserta didik dan proses 
pembelajarannya, tetapi juga rancangan dan pelaksanaan kurikulum, kemampuan dan kemajuan siswa, sarana dan prasarana, serta sumber belajarnya.

Rendahnya kualitas uji kompetensi akibat dari kurangnya sarana dan prasarana yang dimiliki SMK mengakibatkan rendahnya kualitas dan kompetensi lulusan SMK tersebut. Hal ini sangan memepengaruhi profesionalisme kerja lulusan SMK tersebut di dunia kerja.

Sedangkan dampak dari pelaksanaan uji kompetensi ini berupa profesionalisme lulusan SMK, dalam hal ini dideskripsikan tanggapan atasan dari tempat dimana lulusan tersebut bekerja, kesesuaian pekerjaan dengan kompetensi lulusan tersebut, prestasi lulusan tersebut di tempat kerjanya.

Ukuran profesional yang dimaksudkan disini adalah (1) mampu mengembagkan diri secara optimal sesuai dengan kompetensinya, (2) mampu menunjukkan sikap percaya diri dan bertanggung jawab atas prilaku, perbuatan, dan pekerjaannya, (3) membangun dan menerapkan informasi dan pengetahuan secara logis, kritis, kreatif, dan inovatif, (4) menunjukkan sikap kompetitif dan sportif untuk mendapatkan hasil yang terbaik, (5) menghargai adanya perbedaan pendapat dan berempati terhadap orang lain, (6) menguasai kompetensi program keahlian dan kewirausahaan baik untuk memenuhi tuntutan dunia kerja maupun untuk mengikuti pendidikan tinggi sesuai dengan kejuruannya.

Dari uraian diatas dapat diketahui bahwa kualitas pelaksanaan uji kompetensi akan berpengaruh terhadap profesionaisme lulusan SMK Teknologi di Provinsi Bali.

\section{PENUTUP}

Lulusan SMK merupakan tenaga trampil di bidangnya yang harus memiliki kompetensi sebagai tenaga kerja sesuai kompetensi yang dibutuhkan oleh dunia usaha/industri. Untuk itu pihak SMK harus terus membenahi cara pelaksanaan uji kompetensi dengan melakukan kerjasama (MoU) dengan DUDI supaya pihak SMK dapat meluluskan tenaga kerja yang memiliki kompetensi sesuai dengan kebutuhan 
DUDI. Dan dalam melakukan uji kompetensi juga harus melibatkan pihak DUDI (terutama yang telah memiliki sertifikat sebagai asesor), sehingga instrument uji kompetensi yang digunakan harus merujuk pada kompetensi yang dibutuhkan dan memiliki standar tertentu sesuai dengan DUDI tersebut.

Perlu dilakukan standarisasi sarana dan prasarana guna meningkatkan mutu pembelajaran terutama untuk keperluan praktikum, sehingga penguasaan suatu kompetensi yang dipersyaratkan oleh DUDI dapat dicapai oleh siswa. Hal ini akan berdampak pada penguasaan pengetahuan praktis siswa yang dapat diukur melalui uji kompetensi, karena sarana prasaran selalu menjadi kendala bagi beberapa SMK dalam mendukung pelaksanaan uji kompetensi.

Diperlukan kiat-kiat khusus dalam meminimalisasi kendala-kendala yang dihadapi pihak SMK dalam mempersiapkan siswanya untuk menghadapi uji kompetensi, seperti meningkatkan kuantitas dan kualitas sarana prasarana, standarisasi peralatan praktikum, pelibatan asesor dalam uji kompetensi harus dilakukan seobjektif mungkin, peningkatan kualitas dan kompetensi guru melalui pelatihan (minimal bersertifikat asesor), guru juga harus mampu bertindak seobjektif mungkin dalam melakukan uji kompetensi, perlu diadakan survei awal sebelum membuka suatu program di SMK terutama terkait letak geografis dan dukungan dari masyarakat dan lingkungannya, sehingga program yang dibuka sesuai dengan kebutuhan masyarakat sekitarnya.

Rendahnya kualitas pelaksanaan uji kompetensi akibat dari kurangnya sarana dan prasarana yang dimiliki SMK mengakibatkan rendahnya mutu lulusan dan hal ini menjadi pemicu rendahnya profesionalisme lulusan SMK di dunia kerja.

Uji kompetensi lulusan SMK sebaiknya tidak dilakukan di akhir masa studi saja namun perlu juga dipikirkan model uji kompetensi yang bertingkat di setiap jenjang berupa uji kenaikan tingkat. Sehingga seorang siswa SMK baru dapat dinyatakan naik tingkat/kelas kalau yang bersangkutan telah memenuhi kompetensi yang dipersyaratkan pada jenjangnya. Di samping uji kenaikan tingkat tersebut, 
perlu adanya pemikiran untuk mengubah proporsi nilai kelulusan siswa SMK di mana nilai uji kompetensi (praktik) harus jauh lebih besar dari nilai ujian sekolah.

Dalam melaksanakan uji kompetensi, sebaiknya dilakukan ujian praktik terkait kemampuan siswa terhadap penguasaan materi yang dituntutkan oleh indikator-indikator terlebih dahulu sebelum menguji kemampuan siswa dalam penguasaan tuntutan kompetensi dasar dari suatu mata diklat. Pihak SMK sebaiknya melakukan penelusuran alumni (tracer study) agar dapat memantau perkembangan kompetensi lulusannya, untuk selanjutnya dapat dilakukan refleksi terhadap kurikulum di sekolah yang sudah semestinya dilakukan penyesuaian terhadap kebutuhan stake holder, dan refleksi ini sebaiknya dilakukan setiap saat.

\section{DAFTAR PUSTAKA}

Balitbang dan Dikdasmen. 1999(a). Memahami Kurikulum Sekolah Menengah Kejuruan Edisi 1999 Berpendekatan Competency Based dan Board Based. Jakarta: Balitbang dan Dikdasmen, Depdikbud.

Balitbang dan Dikdasmen. 1999(b). Kebijakan Teknis Pengembangan dan Implementasi Kurikulum Menengah Kejuruan. Jakarta: Balitbang dan Dikdasmen, Depdikbud.

Dantes, Nyoman, 2007, "Perspektif dan Kebijakan Pendidikan Menghadapi Tantangan Global", makalah seminar.

Keputusan Menteri Pendidikan dan Kebudayaan Republik Indonesia Nomor 323/U/1997 tentang Penyelenggaraan Pendidikan Sistem Ganda pada Sekolah Menengah Kejuruan. Jakarta: Direktorat Pendidikan Menengah Kejuruan.

Mulyasa E., 2005, Kurikulum Berbasis Kompetensi, PT. Remaja Rosdakarya, Bandung.

Peraturan Pemerintah Republik Indonesia Nomor 29 Tahun 1990 tentang Pendidikan Menengah. Jakarta.

Satuan Tugas Pengembangan Pendidikan dan Pelatihan Kejuruan di Indonesia. 1997. Keterampilan Menjelang 2020 untuk Era Glabal. Jakarta: Departemen Pendidikan dan Kebudayaan.

Tayibnapis Farida Yusuf, 2003, Evaluasi Program, PT. Rineka Cipta, Jakarta.

Implementasi Uji Kompetensi Dan Pengaruhnya Terhadap...( Nyoman Santiyadnya) 
Tim Pengembang MKDP Kurikulum dan Pembelajaran, 2011, Kurikulum dan Pembelajaran, PT. Rajagrafindo Persada, Jakarta.

Undang-Undang Republik Indonesia Nomor 20 Tahun 2003 tentang Sistem Pendidikan Nasional, dilengkapi dengan PP No.19/2005 tentang Standar Nasional Pendidikan. Bandung: Fokus Media.

, Peraturan Menteri Pendidikan Nasional No. 40 Tahun 2008 tentang Standar Sarana dan Prasarana Pendidikan.

, Peraturan Menteri Pendidikan Nasional No. 45 Tahun 2010 Tentang Kriteria Kelulusan Peserta Didik SMK. 